Марија М. Лончар*

Филолошка гимназија

Београд
811.163.41(497.115)

https://doi.org/10.18485/analiff.2019.31.1.9

Originalni naučni rad

Primljen: 10.03.2019

Prihvaćen: 18.06.2019

\title{
СТАТУС СРПСКОГ ЈЕЗИКА НА ТЕРИТОРИЈИ КОСОВА И МЕТОХИЈЕ
}

Политичке и историјске околности које су довеле до драстичног смањења броја српског становништва на територији Косова и Метохије свакако су утицале и на стварни статус српског језика и културе на овим просторима. Мада се у званичним документима на територији КиМ формално и службено албански и српски језик третирају као равноправни, пракса показује да је албански језик у далеко широј употреби будући да се српски међу изворним говорницима, нарочито на југу, свео на употребу у енклавама. Циљ овог рада је да укаже на већ дугогодишњи и актуелни проблем очувања српског језика и културног наслеђа на територији самопроглашене државе Косово кроз преглед досадашњих истраживања и добијених резултата у области пре свега образовања и законодавства, а затим и свега што представља културни живот Срба на тој територији. Рад испитује примену лингвистичких права гарантованих Уставом тзв. Републике Косово и даје предлоге за очување српског језика на Косову и Метохији.

Кључне речи: језичка политика, језичка/лингвистичка права, билингвизам/двојезичност, етницитет, изворни говорник, лингвицид, језички империјализам

\section{Увод}

Политичка ситуација на територији Косова и Метохије (КиМ) одредила је многе аспекте живота мањинског становништва на овим просторима, па тако и положај српског језика и кулуре. Случај и статус КиМ један је од примера да се језичка политика не може сагледати ван друштвено политичког контекста и ван довођења у везу са неким идеолошким циљевима владајућих структура. Мада је српски језик Уставом самопроглашене Републике Косово* дефинисан као службени

* marija164@yahoo.com 
језик напоредо са албанским у државним институцијама још од једностраног проглашења у марту 2008. године, сва је прилика да се у пракси етикетира као непожељан или бескористан с обзиром на бројност изворних говорника албанског. Као последица мање бројности у односу на већинско албанско становништво јавља се и мања друштвена моћ, све тежи положај целокупног неалбанског становништва, а њихов свакодневни живот и културни идентитет доводе се у питање.

Још од једностраног проглашења независности, Косово* тежи да постане пуноправна чланица различитих међународних институција - Уједињених нација, Савета безбедности, ММФ-а, па и Европске уније, што га доводи у обавезу да своју политику усклади са међународним правом и вредностима које пропагирају све високе европске институције. Језичка права свих грађана на КиМ гарантована су Уставом Републике Косово*, Законом о заштити и промовисању права заједница и њихових припадника у Републици Косово* и Законом о употреби језика, који је званично објављен у косовском Службеном листу 1. марта 2007. године. Формално је сваком грађанину гарантовано право на употребу свог матерњег језика у свим косовским институцијама, у судским процесима, образовању, медијима, а као институција задужена за спровођење, очување, промовисање и заштиту лингвистичких права именована је Канцеларија за језике.

Питање КиМ, а самим тим и питање српског језика на овој територији и поред званичних докумената остаје осетљиво. Будући да се језик кроз историју показао као важан фактор у периодима друштвене кризе, нарочито у потврђивању националног идентитета и стварању независних ентитета, јавља се потреба да се укаже на практичну примену законских регулатива у вези са лингвистичким правима и на проблеме у њиховом спровођењу прегледом досадашњих истраживања домаћих и међународних институција. Осим тога, циљ овог рада је да укаже на тренутне ресурсе и могућности очувања српског језика имајући у виду да језик није само обележје идентитета већ и средство за преношење културних садржаја. Рад је подељен на четири целине. Први и други део се тичу закона о употреби језика и његовој примени у пракси, трећи део обрађује употребу језика у систему образовања, четврти говори о улози српских установа и културном аспекту живота Срба на Косову и Метохији којим се чува и негује српски језик, а пети део представља закључак и даје предлоге за успешно спровођење језичких права у будућности. 


\section{1. Правна средства којима се дефинише употреба језика на КиМ}

Употреба језика на територији КиМ одређена је Уставом Републике Косово*, а потом и Законом о употреби језика, као и Законом о заштити и промовисању права заједница и њихових припадника у Републици Косово*. Ова правна документа представљају механизам заштите лингвистичких права свих грађана на мултиетничкој територији Косова и Метохије и обавезују све јавне установе да у пракси једнако третирају језике у службеној употреби омогућавајући грађанима да тако уживају своја језичка права.

Албанским језиком као матерњим на територији КиМ служи се највећи број говорника. Ту чињеницу потврдила је Косовска агенција за статистику ${ }^{1}$ пописом становништва из 2011. на основу кога од укупног броја становника тј. 1,8 милиона, Албанаца има 1.616.869, Срба 25.532, Турака 18.738, Бошњака 27.533, Рома 8.824, Ашкалија 15.436 , Египћана 11.524, Горанаца 10.265 и осталих 2.352. У ову статистику није ушао број Срба у северном делу Косовске Митровице који су овај попис бојкотовали, а процењује се да их у северном делу има око 60 хиљада.

Уставом Републике Косово*2 дефинисано је да су службени језици албански и српски, а да турски, бошњачки и ромски имају статус службених језика на општинском нивоу, односно у оним општинама где говорници ових језика чине најмање $3 \%$ становништва. Знатно мањи проценат неалбанског становништва, тј. њихових заједница појединачно практично отежава уживање права не само на општинском нивоу, већ и на читавој територији КиМ, што је случај са српским језиком који је само формално равноправан са албанским. За делимичну примену закона којима се гарантују лингвистичке слободе и права наводе се недостатак двојезичног кадра у јавним институцијама, недостатак финансија, али и недовољна информисаност и недостатак политичке воље.

1 Страница Косовске агенције за статистику са подацима пописа становништва из 2011. године http://askdata.rks-gov.net/PXWeb/pxweb/sr/askdata/, приступљено 1.9.2017.

2 Текст Устава Косова* на адреси http://www.kryeministri-ks.net/repository/ docs/Ustav1.pdf, приступљено 1.9.2017. 
Закон о заштити и промовисању права заједница и њихових припадника у Републици Косово *3 гарантује равноправност за све становнике КиМ, без обзира на њихову националну или верску припадност, поштује националну, верску, језичку и културну разноликост описујући је као предност за даљи развој демократског друштва. Такође, овај закон подстиче све заједнице да изражавају своју културу и уметност у циљу развијања сопственог идентитета, да се окупљају и оснивају удружења. Овај закон гарантује право и на активно учешће свих грађана у културном, економском, друштвеном и политичком животу на КиМ.

Закон о употреби језика на Косову*4 ступио је на снагу 1 . марта 2007. године, а донет је на основу Међународне конвенције о грађанским и политичким правима, Европске конвенције о заштити фундаменталних људских права и слобода, Оквирне конвенције за заштиту националних мањина и Европске повеље о регионалним или мањинским језицима. Већ у првом члану Закона гарантује се равноправан статус српског и албанског као службених језика на Косову*, као и „право свих заједница да сачувају, одрже и промовишу свој језички идентитет“. Осим тога, у четвртом ставу првог члана овог закона пресликана је и европска идеја о мултикултуралности и вишејезичности друштва, што говори о тежњи косовских институција да достигну европске вредности. Комплетан правни оквир Косова* у вези са употребом језика ослања се на већ постојећа међународна документа издата од стране најутицајнијих организација попут Уједињених нација, Савета безбедности, Савета Европе и Европске комисије. Усклађивање прописа самопроглашене државе Косово* са међународним документима и стандардима схвата се као неопходно за афирмацију у страним круговима како би се стекао утисак о слободном, демократском и правичном друштву на овом простору. Поштовање права, у овом случају језичких, ипак је још увек само делимично, а то потврђују и међународне институције које већ извесно време спроводе различита истраживања у вези са прогресом у остваривању лингвистичких права свих неалбанских језичких заједница.

3 Закон о заштити и промовисању права заједница и њихових припадника у Републици Косово на адреси http://www.gazetazyrtare.com/e-gov/index. php?option=com_content\&task=view\&id=148\&lang=bh, приступљено 1.9.2017.

4 Текст Закона о употреби језика на Косову* доступан на адреси http://www. komisioneri-ks.org/repository/docs/2006_02-L37_sr.pdf приступљено 1.9.2017. 


\section{2. Спровођење закона и изазови}

Лингвистичка права углавном прво асоцирају на права мањинског или мигрантског становништва које се кроз процес интеграције или, у крајњем случају асимилације, прилагођава новој географској и друштвеној средини истовремено покушавајући да сачува свој језик, културу и обичаје. На територији Косова и Метохије не говоримо, пак, о становништву измештеном у географском смислу, већ о малобројним српским и другим неалбанским заједницама које су остале на поднебљу са кога потичу и њиховом проблему остваривања језичких права. Српски језик се од осталих језика мањинских заједница разликује у томе што пред законом има равноправан статус са албанским иако се и поред највиших гаранција тај статус не практикује. Равноправан статус службених језика подразумева истовремено присуство ових језика на свим јавним местима у земљи, у свим државним институцијама, јавним исправама и документима без фаворизовања неког језика или дискриминације говорника једног језика у односу на други. За мониторинг имплементације закона у области остваривања језичких права свих језичких заједница на КиМ именована је Канцеларија повереника за језике. Основна улога овог тела именованог од стране косовске владе је да контролише примену Закона о језику, укаже на неправилности и омогући свим мањинским заједницама да у обављању свакодневних активности у потпуности остварују своја права. Под свакодневним активностима пре свега се мисли на услуге које пружа држава и запослени у различитим установама - у зградама општина и полиције ради регулисања различитих врста докумената и образаца, а потом и у здравственим, образовним установама итд.

\section{1. Канцеларија повереника за језике}

Канцеларија повереника за језике тренутно је једино тело на територији КиМ које се експлицитно и активно бави праћењем спровођења закона, очувања, промоције и заштите службених језика, осигуравања њиховог равноправног статуса на Косову, као и заштите и очувања језика заједница чији матерњи језик није службени језик. Канцеларија је почела са радом 2007. године у виду Комисије за је-

5 Подаци о Канцеларији повереника за језике на адреси http://www.komisioneri-ks.org/?page=4,1, приступљено 15.8.2017. 
зике, али је 2012. преименована у Канцеларију за језике, а потом и Канцеларију повереника за језике уз додатна финансијска средства страних организација, нарочито ОЕБС-а, ради боље и успешније имплементације Закона о језику. Од 2013. године Канцеларија је укључена у низ теренских акција како би се подигла свест о равноправној употреби службених језика на централном и локалном нивоу, затим промовисала језичка права свих грађана који живе на КиМ, али и да би се промовисала улога Канцеларије као надзорног органа у спровођењу овог закона.

Канцеларија повереника за језике делује самоиницијативно, али и по основу жалбе појединаца, посредује између грађана и установа на КиМ и функционише као саветодавно тело и становништву и институцијама како би заједно остварили своја законска права и испунили обавезе. Након реформирања 2012, први задатак Канцеларије био је да пронађе контакт особу у општинама на КиМ која би правовремено информисала о свим језичким питањима, људским ресурсима тј. усменим и писменим преводиоцима, језичким проблемима, захтевима и жалбама на локалном нивоу. Овај задатак предвиђен Уредбом о Канцеларији повереника за језике био је предуслов за формирање Мреже за језичку политику, која је један од механизама за пружање подршке у раду. Извештај ОЕБС-а (ОЕБС 2014б:11) наводи да је од укупно 34 општине ${ }^{7}$ само 16 именовало контакт особу за језичка питања, док преосталих 18, због неразумевања својих обавеза, још увек нема одговор на захтеве Канцеларије повереника за језике па тако Мрежа за језичку политику није ни формирана. Ипак, верује се да ће проактивна политика, коју Канцеларија спроводи од 2012. године, утицати на боље разумевање и успешнију сарадњу са свим општинама на КиМ како би примена лингвистичких права била свеобухватна.

6 Текст Уредбе на адреси http://www.komisioneri-ks.org/repository/docs/ Uredba_Regulore_Regulation_07_2012.pdf, приступљено 15.8.2017.

7 Укупан број општина на КиМ је 38 укључујући четири општине у северном делу КиМ у којима Срби чине већински део становништва - Зубин Поток, Лепосавић, Звечан и Северна Митровица. Истраживање Канцеларије повереника за језике обухвата 34 општине јужно од Ибра, у којима Албанци чине већински део становништва. Осим тога, Канцеларија повереника за језике је именована од стране премијера Косова*и као установа не представља ауторитет за општине на северу КиМ. ОЕБС у својим извештајима и истраживањима на КиМ увек наводи 38 општина. 


\section{2. Спровођење закона на општинском нивоу}

На територији КиМ постоје укупно 34 општине и у свакој од њих су у службеној употреби најмање два језика - албански и српски, што је гарантовано Уставом Косова* и Законом о употреби језика. Поред албанског и српског језика, који представљају службене језике на централном нивоу, службени језици могу бити и турски и босански. Службени језик на локалном нивоу је језик припадника заједница које сачињавају више од 5\% становништва општине и који није службени језик на централном нивоу (Закон о употреби језика, члан 2.3). Турски језик је службени у општинама Призрен и Мамуша, а босански у општинама Драгаш, Пећ и Призрен. Језик припадника заједница који сачињавају више од $3 \%$ становништва у општини има статус језика у службеној употреби на општинском нивоу. Тако је турски у службеној употреби у општинама Гњилане, Јужна Митровица, Приштина и Вучитрн $^{8}$, а босански у општини Исток. Што се тиче ромског, ниједна општина није признала овај језик као језик у службеној употреби, мада заједнице косовских Рома традиционално говоре својим језиком у оним општинама у којима живе (ОЕБС, 2014б:5). Ромски језик је углавном сведен на приватну употребу, али се употребљава и у учионицама у којима се држи настава на ромском, како у оквиру албанског тако и у оквиру српског образовног система ${ }^{9}$. На општинском нивоу, особе којима је ромски матерњи имају проблема у комуникацији са службеницима приликом остваривања својих права и добијања услуга, јер нико од запослених не говори њиховим језиком. Ове особе су тако приморане да све захтеве у јавним установама упућују на једном од два службена језика ${ }^{10}$.

Успешна комуникација са грађанима једна је од најважнијих обавеза свих државних институција. Она се остварује кроз формула-

8 Општине Гњилане, Јужна Митровица, Приштина и Вучитрн су турски језик као службени признале 2007. и 2008. године.

9 Српски образовни систем се реализује у северном делу Косова, где већинско становништво чине Срби, и у енклавама на КиМ, јужно од реке Ибар.

10 Треба имати у виду да се општински захтеви у највећој мери подносе на албанском језику, као и да је незнатан број службеника на Косову двојезичан на оба службена језика, претежно старија популација. Један од кључних проблема у комуникацији у општинама је управо једнојезичност запослених у јавним институцијама. 
pe, захтеве, дописе, обавештења, саопштења и конференције за штампу, конкурсе, интернет странице, обичну или електронску пошту, летке, брошуре, приручнике, огласе итд. Сви ови начини комуникације морају бити на службеним језицима истовремено како би се поштовала језичка равноправност. Међуинституционална комуникација се такође мора вршити на службеним језицима. Саветодавни одбор Оквирне конвенције за заштиту националних мањина ${ }^{11}$ (2013:35) истиче да су сви вишејезични натписи, обавештења и огласне табле у канцеларијама општина у којима се пружају услуге грађанима од посебног значаја јер интегришу недоминантне језичке групе и приказују их као поштоване и прихваћене припаднике друштва.

Поред подизања свести о правима и обавезама, спровођења истраге о потенцијалним случајевима кршења законских одредби у погледу остваривања језичких права, Канцеларија повереника за језике посредује између подносиоца жалби и институција. Процедура интервенције Канцеларије почиње од разматрања саме жалбе. Ако се установи да је жалба у домену надлежности Канцеларије, после разматрања следи процес медијације. Институције добијају препоруке или савете и најчешће обавештавају Канцеларију о примени корекција у раду. Канцеларија након изнесене жалбе грађана прати спровођење препорука за даљи рад ${ }^{12}$. Проблеми у комуникацији на општинском нивоу у вези са остваривањем језичких права најчешће се односе на једнојезичност запослених. Грађани који говоре српским, босанским или турским језиком ретко могу наићи на разумевање међу запосленима који говоре албанским.

\section{3. Проблем људских ресурса и квалитета превода}

Да би сваки грађанин чији је матерњи језик у службеној употреби на Косову* могао да оствари своја језичка права при подношењу усмених и писмених захтева и докумената, неопходно је да општина располаже квалификованим људским ресурсима који ће обезбедити

11 Саветодавни одбор Оквирне конвенције за заштиту националних мањина, Tpeће мишљење о Косову, март 2013, http://www.coe.int/t/dghl/monitoring/minorities/3_FCNMdocs/PDF_3rd_OP_Kosovo_en.pdf, приступљено 27.9.2017.

12 ОЕБС-ов документарни филм о раду Канцеларије повереника за језике од 26.9. 2014. на адреси https://www.youtube.com/watch?v=pSI4HkQJFzc приступљено 15.8.2017. 
квалитетан писани превод документације и захтева, као и усмени превод током разних састанака. Мада ОЕБС, као међународна организација, годинама уназад прати примену Закона о језику ${ }^{13}$ на Косову*, извештај о спровођењу овог Закона из марта 2015. указује на проблем једнојезичности службеника у већини општина, иако је Закон ступио на снагу 2006. године. У марту 2015. објављен је и извештај ${ }^{14}$ Канцеларије повереника за језике у сарадњи са Развојним програмом Уједнињених нација (UNDP) и Европским центром за мањинска питања на Косову*(ECMI) који детаљно указује на проблем људских ресурса при пружању преводилачких услуга. Укупан број језичких стручњака на територији 34 општине на Косову* износи 52. Већина, односно њих 48 (92\%), има албански као матерњи језик. Две особе су изворни говорници босанског, а преостале две турског језика. Међу језичким стручњацима нема оних којима је матерњи језик српски. 46 професионалаца од 52 је проценило ниво познавања страног језика, тако да њих 11 тврди да језик познаје на нивоу Ц2, 19 на нивоу Ц1, 5 на нивоу Б2, 3 на нивоу Б1, 2 на нивоу А2 и 6 на нивоу А1 Заједничког европског референтног оквира за живе језике. Само 7 од 52 има сертификовано знање страног језика (КПЈ, 2015:31). Тек 17 запослених има факултетску диплому, а само 9 из области филологије. Ова статистика говори много о квалитету превода, имајући у виду да само факултетска диплома без добре праксе и сталног усавршавања није гарант за квалитетно пружање преводилачких услуга. Чињеница да на територији Косова* не постоји могућност стицања универзитетске дипломе из области усменог или писменог превођења на службеним језицима Косова*, као и одсуство адекватне професионалне обуке или програма стручног усавршавања запослених преводилаца негативно утиче на изградњу капацитета у јавним установама. До момента анкетирања запослених преводилаца у јавним установама није одржан ниједан програм обуке за преводиоце. Осим са професионалном обуком, преводиоци који су запослени у општинама суочавају се и са проблемом обима посла. Канцеларија повереника за језике ука-

13 Текст Закона о употреби језика на Косову* доступан на адреси http://www. komisioneri-ks.org/repository/docs/2006_02-L37_sr.pdf приступљено 1.9.2017.

14 Office of the Language Commissioner (2015) Monitoring and Evaluation of Language Rights in Kosovo, извештај доступан на адреси http://www.komisioneri-ks. org/repository/docs/Anglisht_Finale_160315.pdf, приступљено 15.9.2017. 
зује да су сви активни преводиоци преоптерећени и да статистички гледано сваки од њих треба да преведе 10,23 страна дневно. Овај податак говори много о квалитету самог превода, а треба узети у обзир и чињеницу да се не прави дистинкција између преводилаца, тумача и лектора. Малобројни квалификовани кадар резултат је и недовољног издвајања новчаних средстава за преводиоце, што ову професију чини мање популарном у односу на друге. Од 34 општине ниједна до сада није формирала јединицу за језичке услуге, 5 не пружа никакав вид интерне језичке подршке, 27 пружа услуге лекторисања, писменог и усменог превођења унутар установе, а само 2 општине пружају услуге интерног лекторисања.

Програми обуке за службенике у јавним установама одржани су у периоду између 2013. и 2014. године у циљу побољшања њихових језичких способности, а потом и успешније комуникације са мањинским становништвом. Настава је организована уз подршку ОЕБС-а на српском и албанском језику у 14 општина и била је добро прихваћена од стране запослених у јавним установама на Косову*. Европски центар за мањинска питања је 2015. године организовао 23 курса албанског и српског језика за службенике јавних управа. Настава за укупно 286 полазника је била организована у општинама Каменица, Гњилане, Вучитрн, Штрпце, Обилић, Партеш, Ранилуг, Призрен, Липљан, Ново Брдо, Клокот, Грачаница, Северна Митровица, Зубин Поток, Лепосавић и Звечан ${ }^{15}$. Интервју који су полазници дали за Европски центар за мањинска питања на Косову* (ECMI) указује да су ови запослени препознали значај познавања два службена језика на територији КиМ и да су спремни да побољшају своју језичку компетенцију на другом службеном језику како би олакшали комуникацију унутар установе у којој раде и били ефикаснији у свом послу. Ова иницијатива је значајна и због тога што позитивно утиче на радно окружење и помаже у превазилажењу предрасуда према другим етничким и језичким заједницама.

У Извештају о спровођењу закона о употреби језика од стране косовских општина из 2008. године (2008:5) ОЕБС је указао на безбедносне перцепције у вези са кретањем и коришћењем матерњег

15 Утисци полазника и наставника који су држали обуку могуће је видети у интервјуу на адреси https://www.youtube.com/watch?v=tkcwGQHjNxY, приступљено 17.9.2017. 
СТАТУС СРПСКОГ ЈЕЗИКА НА ТЕРИТОРИЈИ КОСОВА И МЕТОХИЈЕ

језика на јавним местима у којима живи већинско становништво. Испитаници који говоре српским и ромским језиком изразили су безбедносну забринутост у погледу употребе матерњег језика на јавним местима, нарочито у општинама Гњилане, Митровица и Клина. Такође, у мањем броју општина (нпр. Клина) запослени који говоре српским језиком нису се осећали слободним да користе свој матерњи језик у контакту са групом колега, или нису били у могућности да непосредно комуницирају на српском језику са општинским службеницима, који су захтевали преводиоца као услов да се састану (Урошевац). Ови званичници су наводно били у стању да говоре српски, али нису били вољни да га користе (ОЕБС, 2008:6). Очигледна тензија, нетрпељивост и предрасуде указују на потребу за предузимањем мера за стварање погоднијег радног окружења у коме ефикасније треба да раде запослени свих присутних националности.

\section{4. Превод интернет страница јавних установа и употреба језика у медијима}

Члан 7 Закона о употреби језика налаже да све општинске институције примењују једнакост службених језика општине, па тако и све информације морају бити равноправно доступне на службеним језицима и језицима у службеној употреби. Будући да општине информације обезбеђују и електронским путем, неопходно је да се спроведу мере како би се правовремено ажурирали сви релевантни подаци на оба службена језика и на језике у службеној употреби. Подаци ОЕБСа указују да ниједна општина не поштује у потпуности обавезу равноправне употребе оба службена језика (ОЕБС, јун 2008:7). Извештај Канцеларије повереника за језике (2014:19) истиче да свака општина има своју интернет страницу ${ }^{16}$, али да је само седам општина у потпуности ускладило интернет презентацију према језичким прописима. У случају Призрена, на пример, општине у којој су поред албанског и српског језика у употреби традиционално турски, а потом и босански као језик у службеној употреби, нема презентације на босанском језику. Информације тј. новости се не ажурирају правовремено, а подаци о општини, услугама, пројектима и конкурсима постоје искључиво на

16 Листа са интернет страницама свих општина на територији КиМ налази се на адреси http://kk.rks-gov.net/, приступљено 19.9.2017. 
албанском језику. Превод на српски језик је минималан, урађен само за хоризонтални или вертикални изборни мени који није адекватно ни преведен ни написан. Уз одсуство квалификованог и компетентног кадра, као и политичке воље, а узимајући у обзир демографске податке, тешко је уочити значајан прогрес у примени закона у овом сегменту. Значај објављивања конкурса на другим језицима огледа се и у томе што би се на тај начин могло побољшати запошљавање припадника заједница који су недовољно присутни у јавним установама.

Употреба језика у медијима регулише се такође кроз Закон о употреби језика на Косову*. Док приватни медији имају право да користе језик по свом избору, јавни сервис је у обавези да омогући једнак медијски простор и приступ информацијама свим језичким заједницама на Косову*17. Јавни преносиоци треба да промовишу културну различитост и вишејезични карактер Косова*, што је у складу са европском идејом о вишејезичности и вредностима које се негују у Европској унији. Ту улогу има Радио-телевизија Косово (RTK) ${ }^{18}$ која свој програм реализује на четири телевизијска канала и две радио станице објављујући новости на шест језика - албанском, српском, босанском, турском, ромском и енглеском језику. Приватне телевизије попут TV21, KTV и Klankosova TV нису у обавези да емитују програм на оба службена језика и њихове интернет странице су само на албанском језику. Поред информација на језицима мањина, РТК је уз подршку USAID-а у периоду од септембра 2015. до фебруара 2016. емитовао емисије дужине 20-30 минута чији циљ је био да се побољша међуетничка комуникација кроз различите приче са позитивним исходима. Садржај прича покривао је актуелне економске, друштвене и политичке теме о којима су говорили новинари, представници власти, уметници итд. Снимљен је и документарац о уметницима албанске и српске националности који заједно желе да врате славу подељеног града Митровице као центра рокенрола у тој области. Осим РТК, ове емисије преносиле су и телевизијске станице РТВ Ким, РТВ Пулс, РТВ Мир и РТВ Херц (USAID, 2017:11).

Српских телевизијских и радио станица на КиМ по бројности је далеко мање у односу на албанске и оне појединачно нису у могућ-

17 Погледати Закон о употреби језика, чланови 25 и 26.

18 Интернет страница РТК доступна на http://www.rtklive.com/rtk2/?id=6, приступљено 20.9.2017. 
ности да покрију целу територију Косова*. Имајући то у виду, станице су се ујединиле, те је тако формирана Косовска медијска асоцијација КОСМА, удружење медија који емитују програм на српском језику. Мрежу српских медија на КиМ у оквиру КОСМА чине поменуте РТВ „КиМ“ из Чаглавице код Пећи, Радио „Контакт +“ из Косовске Митровице и Радио „Клокот“ јужно од Гњилана, а присутне су и РТВ „Мир“ из Лепосавића, ТВ „Мост“ из Звечана, Радио „Макс“ из Шилова, Радио „Хит ласер“ из Пасјана, Радио „Антена““ из Чаглавице, Радио „Елит“ из Племетине, Радио „Сочаница“, Радио „Импулс“ и Радио „Бубамара“ (општина Лепосавић). ${ }^{19}$

\section{5. Употреба језика на уличним и осталим топографским знацима}

Закон о употреби језика у члану 9.2 налаже да „званични знаци који означавају или укључују имена општина, села, улица и осталих јавних места [буду] означени на званичном језику и на језицима заједница које имају статус званичног језика у општини“. Међународне организације су годинама уназад пратиле напредак општина на Косову* у области примене закона, а о различитим сегментима примене закона о језику извештавала је и косовска Канцеларија повереника за језике. У извештају о Спровођењу закона о употреби језика из јуна 2008. године ОЕБС је истакао да су само 20 од 34 административне јединице усвојиле одлуку или уредбу о називима улица. У 17 општина сви или већина назива улица и јавних места наведени су само на једном службеном језику (ОЕБС, 2008б:7). Сходно броју албанских заједница, већина топографских знакова урађена је искључиво на албанском језику. Проблем са вишејезичним натписима огледа се у томе што су називи на српском језику, који најчешће стоје иза албанских назива, прецртани, обојени или на било који други начин оштећени, па чак и уклоњени. Постоје и они називи на српском језику који су нетачни или погрешно написани. Спречавање примене закона настаје и у вези са називима улица, које у 78\% случајева носе лична имена из већинских заједница, што се може протумачити као облик потенцијалне дискриминације. Овај проблем би се могао решити тако

19 Листа специјалних средстава информисања на адреси http://www.ian.org. rs/kosovo-info/srpski/files-index/List-of-outlets-for-IDPs-SERB.pdf, приступљено 15.10.2017. 
да се код општина инсистира да називи улица буду такви да се могу несметано превести на други службени језик и језике у службеној употреби (ОЕБС, 2008:7). Повереник Канцеларије за језике у документарном филму о Канцеларији ${ }^{20}$ наводи и недостатак капацитета као проблем који спречава потпуну примену Закона о употреби језика на Косову*. Као пример наводи случај аеродрома у Приштини који је ангажовао агенцију за превод на албански, српски и енглески која није одрадила посао у складу са оним што је било договорено. Са многих натписа на новом терминалу је српски језик у потпуности изостављен. Извештај ОЕБС-а о процени права заједница из 2015. године ${ }^{21}$ указује на благо побољшање у области примене Закона о језику када је реч о натписима, називима улица, села и другим топографским знаковима. Напредак је уочен у општини Штрпце која је у локалним медијима пријавила и отворено осудила оштећење путних знакова (КПЈ, 2014:23) 22.У већини општина се законске одредбе у потпуности поштују, у девет општина се поштују делимично, а у четири општине (уз четири општине на северу Косова*) натписи су само на већинском језику. Седам општина уз четири на северу и даље не поштују прописе (ОЕБС, новембар 2015:12). За четири општине на северу КиМ прописи се не примењују јер становништво у овом делу не признаје законе и прописе самопроглашене државе Косово*. Са лингвистичке стране, овај случај се може објаснити и страхом од лингвицида, будући да је српски језик угрожен и све мањим бројем изворних говорника на простору КиМ.

\section{3. Језици у образовању и могућности језичке едукације - учења службених језика}

Постепено раздвајање, а потом и нестанак комуникацијских веза између Срба и Албанаца на КиМ почели су много пре једностраног проглашења независности. Крајем шездесетих година прошлог

20 Документарни филм о раду Канцеларије повереника за језике на адреси https://www.youtube.com/watch?v=PXs6EevD-gA, приступљено 1.9.2017.

21 Извештај ОЕБС-а о процени права заједница из новембра 2015. године доступан је на адреси http://www.osce.org/sr/kosovo/209971?download=true, приступљено 15.9.2017.

22 У извору се наводи да је до ове информације дошао ОЕБС током интервјуа. 
века на Косову је укинута обавеза учења нематерњег језика, што се тада могло протумачити као демократска одлука, а данас су последице јасне. Као две највеће косовске заједнице, албанска и српска, које ни претходно нису биле у најбољим односима, још више су се раздвојиле. Албанцима је омогућено да комплетно школовање заврше на матерњем језику без обавезе учења српскохрватског, чиме су њихова лингвистичка права максимално остварена, али је њихов професионални развој ограничен само на албански језички простор (Бугарски, 2005:84). Ако погледамо ситуацију данас, и српска заједница унутар албанске већине има могућност школовања на свом матерњем језику и, може се рећи, остварује своје језичко право у домену образовања. Ипак, лингвистичка права подразумевају и права на комуникацију у јавним и другим доменима без језичких баријера или проблема коришћења одређеног језика, тј. право на равноправно и активно учешће у демократским, економским, образовним и професионалним процесима унутар дате политичке заједнице, најчешће државе, што Скутнаб-Кангас (2006:276) назива инструменталним лингвистичким правима ${ }^{23}$. Мада су ова права гарантована уставом и законима, у пракси је на КиМ јужно од Ибра српски језик ограничен на приватну употребу јер се његови говорници не осећају безбедно да га користе изван простора енклаве. Албански језик је, и поред законски њему равноправног српског на читавој територији, доминантан језик како по броју говорника тако и у стратешком језичком планирању. У косовском наставном плану за мањинско становништво је обавезно учење једног службеног језика, свакако албанског јер српског и нема у понуди. На тај начин се онемогућава повећање броја говорника српског језика на овој територији плански, што доводи до лигвицида - убиства језика или лингвистичког геноцида. Скутнаб-Кангас (2004:7), позивајући се и на Џошуу Фишмана, тврди да су школе тј. образовни системи учесници у извршавању лингвистичког геноцида, убиства језика који су, иначе, вековима опстајали. У случају српског на територији Косова и Метохије, лингвицид се извршава пре свега смањењем броја изворних говорника језика, у нашем случају српског, кроз отежавање

23 Са друге стране постоје и експресивна лингвистичка права које ауторка Скутнаб-Кангас (2006:276) дефинише као право појединца да се идентификује са датом групом или заједницом у лингвистичком, а потом и у етничком, културном и сваком другом смислу. 
услова за живот, немогућношћу запошљавања, угрожавањем слободе кретања и јавне комуникације и сл. Као резлутат нестаје један језик са територије на којој је вековима био у званичној употреби.

Да би српска мањинска заједница опстала, пре свега на простору јужно од Ибра, неопходно је да познаје албански језик макар на нивоу основне комуникативне компетенције. Ово важи и за све мањинске заједнице на Косову или било где у свету како би се живот у мултиетничкој средини несметано одвијао. Успешна интеграција, али не и асимилација, кроз језик неопходна је за нормално функционисање и свакодневни живот у таквој средини. Ипак, вишедеценијски лоши односи између Срба и Албанаца на КиМ са кулминациојом догађаја из 1999. године, мартовског погрома 2004. као и након једностраног проглашења независности 2008. не подстичу локално српско становништво на учење албанског. Ситуација данас рефлектује једну асимилациону политику косовских планера, па тако долазимо и до лингвистичког империјализма кога Филипсон (2006:348) дефинише као неједнаку размену и неједнака комуникативна права појединаца или група одређена у њиховим компетенцијама у појединим језицима, која резултирају неједнаким бенефитима у систему који озакоњује и сматра природном овакву експлоатацију. За развијање односа међусобног разумевања и толеранције чини се да ће бити потребно много времена и напора уз системско мењање ствари и надзор високих европских институција у којима се негују ове вредности.

На територији Косова и Метохије у употреби су два засебна образовна система - један који се изводи на албанском језику и други на српском. Већи део образовних установа функционише на албанском, док се српски образовни план реализује у општинама на северу Косова и Метохије и у енклавама јужно од реке Ибар у којима живи српско становништво. Припадници националних мањина имају право на образовање на свом језику и очување свих елемената свог идентитета. Школе у којима се настава одвија на српском језику могу да користе наставне уџбенике које је израдило Министарство просвете Републике Србије након што о томе обавесте Министарство за образовање, науку и технологију Косова (МОНТ). Уколико МОНТ уложи приговор на одабир наставних уџбеника на српском језику, случај се прослеђује Независној комисији која накнадно разматра да ли је уџбеник или наставни програм усклађен са Уставом Републике Косово* и ва- 
жећим законима. МОНТ на овај начин филтрира садржаје из области српског језика и књижевности, као и историје која се за овај простор неједнако тумачи. Тако се велики део културног наслеђа једног народа доводи у питање. МОНТ нема на располагању ни наставне планове ни уџбенике на српском језику који би се користили у основним и средњим школама на КиМ (МОНТ 2010:1), а Стратешким планом за образовање на Косову за период 2017-2021. наводи се да ће школе у којима се настава одвија на српском језику наставити да функционишу изван косовског система образовања (МОНТ, 2016:15) ${ }^{24}$.

Савет безбедности је 2009. године објавио извештај о мањинским заједницама на Косову* у основном и средњем образовању и указао на проблем који постоји у примени двоструког наставног плана $^{25}$. Косовски Албанци који се школују по косовском курикулуму ни у једном облику немају наставу на српском, као што је случај и са српским ученицима који се школују по плану и програму Министарства просвете Републике Србије и који немају ниједан час албанског језика (ОЕБС, 2009:2). Два потпуно одвојена образовна система, према мишљењу ове међународне организације, не могу створити погодну климу за међусобно разумевање, толеранцију и интеграцију.

Осим тога, у одељењима где наставни језик није службени, ученици су у обавези да изаберу службени језик који ће учити. Међутим, у косовским наставним плановима на босанском и турском језику други службени језик није предвиђен као обавезан већ као изборни предмет. Родитељи користе ову прилику да им деца имају два додатна часа албанског језика, док српски практично не могу да изаберу јер га нема у косовском наставном плану (ОЕБС, 2009:22). Неодговарајући и недовољни часови албанског језика доводе до слабог учења, мањих могућности за интеграцију и запошљаање. Ни српски наставни план не даје могућност учења албанског језика као другог службеног језика што појачава јаз између албанског и неалбанског становништва. Изузетак су горански ученици који уче по српском наставном пла-

24 МОНТ (2016) Стратешки план образовања на Косову 2017-2021, доступно на адреси https://masht.rks-gov.net/uploads/2017/02/20161006-spok-2017-2021-1.pdf, приступљено 18.9.2017.

25 OSCE (2009) Kosovo non majority communities within the education system, текст доступан на адреси http://www.osce.org/kosovo/36978?download=true, приступљено 1.9.2017. 
ну и имају два часа албанског језика недељно (ОЕБС, 2009:23). Због ове ситуације постоји опасност да и у будућности запослени у јавним службама не познају два службена језика, чиме се угрожава спровођење Закона о језику.

Модел образовања на Косову* дефинисан је Законом о основном и средњем образовању који је предложен од стране МОНТ-а у јулу 2002. године. Разреди су подељени по нивоима. У првом су предшколско, први и други разред, у другом трећи, четврти и пети, у трећем степену су шести и седми, у четвртом су осми и девети, у петом десети и једанаести разред, а у шестом нивоу је дванаести разред. По овом моделу основно образовање траје 5 година, првих пет разреда тј. узраст од 6 до 12 година, ниже средње образовање траје 4 године, разреди од 6. до 9. тј. узраст од 12 до 15 година, и више средње образовање траје 3 или 4 године у зависности од наставног плана, разреди 10-12 или узраст од 15 до 19 година (МОНТ, 2012:32). Матерњи језик учи се од предшколског узраста до краја 12. разреда. Први страни језик је енглески и он се учи од првог степена образовања, па све до краја средњег високог образовања. На првом степену образовања енглески се учи првенствено кроз игру, цртеже и песме са нагласком на говор, а у наредним степенима наставља се са читањем и писањем (МОНТ, 2012:34). Енглески језик, на нивоу средње школе, на последња два степена курикулума, учи се као предмет примењен у осталим областима, а посебно у школама професионалног образовања. Овде се енглески као први страни језик може протумачити као језик струке, али и као потенцијал за формирање двојезичне наставе. Албански језик за ученике који не припадају албанској заједници учи се почевши од другог степена наставног плана и програма, тј. трећег разреда (МОНТ, 2012: 38). Будући да се Срби на Косову образују у складу са српским наставним планом и програмом, настава албанског језика за неалбанске заједнице односи се на Бошњаке, Турке, Горанце, Египћане, Ашкалије, Роме и друге заједнице искључујући српску. Учење албанског језика међу припадницима наведених заједница објашњава се као учење службеног језика државе у којој ове заједнице живе. Овде треба нагласити да српски језик као други службени језик равноправан албанском не стоји у понуди неалбанским заједницама напоредо са албанским језиком. Српски језик се формално у плану и програму провлачи као други страни језик, поред босанског и тур- 
ског, али и поред немачког, италијанског, француског и других језика који се у курикулум уводе на трећем степену образовања, тј. од шестог разреда (МОНТ, 2012:38) У стручним школама и гимназијама тј. вишој средњој школи могуће је учити и трећи страни језик. Постоји настава на већ поменутим језицима, а у гимназијама се могу учити и класични језици, латински или старогрчки.

Изборна настава у основном и средњем образовању на Косову* може се реализовати на основу предлога МОНТ-а или школе. Ученици могу да присуствују изборној настави у виду допунских часова из обавезних предмета, затим другог или додатног страног језика, нових курсева као што су грађанско васпитање, курс из здравства, права и слобода човека, технологија информисања и комуникације, етике итд, потом тема из живота и екскурзије.

Наставни план и програм на страном језику тренутно се изводи у интернационалним школама. Интернационалне школе нуде наставу на енглеском језику од предшколског нивоа до краја средње школе. У америчким интернационалним школама наставни план и програм се реализује по америчком курикулуму. Осим енглеског језика, учи се албански као локални језик и страни језици - немачки, италијански, француски итд. Промоција страних језика на Косову* потпомогнута је радом присутних културних центара - Амерички кутак, Гете институт, Француски културни центар, Италијански културни центар који има канцеларију у Приштини. Неке земље попут Шпаније, чији се језик може учити у вишим разредима средње школе или гимназијама, немају свој културни центар јер нису признале независност Косова*.

Мултиетничка и мултилингвална средина представља погодно тло за формирање билингвалне наставе и двојезичних одељења како би у једном тренутку дошло до интеграције комплетног друштва. Било да је реч о слабом облику билингвизма или јаком (Бејкер, 2011:240), чини се да на овој територији још увек нема адекватних програма који би обухватили оба службена језика ни у једном образовном систему. За то је могуће навести неколико разлога. Први је недостатак политичке воље већинског албанског становништва, које, ма колико бројније у односу на све друге народе на КиМ, још увек тражи афирмацију у различитим међународним организацијама. Ако бисмо се ослонили на концепт језик-нација-држава, за потрвђивање независности, сваки други језик осим албанског би се сматрао сметњом 
или препреком ка том циљу. Други разлог се односи на корисност познавања мањинских језика, у овом случају службеног српског који је сведен на употребу у северном делу КиМ и на енклаве. Трећи, из перспективе српског становништва, односио би се на то да би учење албанског погоршало статус већ угроженог српског језика на КиМ. За српско становништво статус српског као службеног језика говори о његовој присутности на територији, о обележју једне етничке заједнице и дела идентитета. Најзад, осетљивост на национални и језички идентитет код припадника обе заједнице огледа се и у непоштовању правила о двојезичним уличним и другим топографским знацима.

\section{4. Очување српског језика и културе кроз рад српских државних и верских институција на КиМ}

Канцеларија за Косово и Метохију при Влади Републике Сpбије поред осталих послова надлежна је за образовање, деловање Српске православне цркве и обнову и заштиту духовног и културног наслеђа ${ }^{26}$ на територији КиМ. У сектору за јавне службе Канцеларије за КиМ обављају се праћења, анализе потреба и предлагања мера за унапређење образовног система у овој покрајини. У сарадњи са Министарством просвете Републике Србије, Канцеларија за КиМ помаже у спровођењу српског образовног плана на територији КиМ кроз набавку и дистрибуцију уџбеника за ученике основних и средњих школа, обнову образовних установа и опремање учионица, као и организовање обилазака и путовања ученика са КиМ у друге делове Србије. Од 2006. до 2013. сваке године је одржавана манифестација „Мала матура - велико срце“ у организацији Канцеларије, Министарства просвете, Града Београда, МУП-а и београдских основних школа у оквиру које је више од хиљаду малих матураната са КиМ неколико дана боравило у Београду и дружећи се са својим вршњацима упознавало глави град.

Према подацима којима располаже Канцеларија ${ }^{27}$, до 1999. године на КиМ се школовало око 45300 ученика у основним школама и

26 О надлежности Канцеларије за КиМ на адреси http:/www.kim.gov.rs/ nadleznost.php, приступљено 20.9.2017.

27 Подаци добијени из интервјуа са представником сектора за образовање Канцеларије за КиМ, септембар 2017 
око 14000 у средњим школама. Од 1. септембра 1999. тај број је драстично смањен и данас износи око 14000 ученика у основним школама и око 5500 ученика у средњим школама и гимназијама. Наставни кадар у северном делу КиМ је стручан, односно сви запослени и ангажовани наставници у овом делу раде посао за који су се школовали. Након 1999. је у неком тренутку било импровизације наставе у централним и јужним деловима КиМ (долазили су наставници и из централних делова Србије по потреби), али се временом стање мењало у корист струке. Ипак, проблем и даље постоји у тзв. енклавама у којма се настава изводи према постојећим условима. Најтежа ситуација за извођење наставе на српском језику је у Метохији и у централном делу КиМ, нарочито у Гори, где преовладава осећај страха свих неалбанских заједница. У ОШ „Браћа Алексић“у Л Липљану, на пример, ученици уместо понедељком, наставу имају суботом из безбедносних разлога ${ }^{28}$. Родитељи их свакодневно прате на путу до школе и чекају када се настава заврши.

На КиМ постоје и тзв. мултиетничке школе у којима се заједно школују и Срби и Албанци. Настава се не изводи истовремено, већ се српска деца школују пре подне, а албанска после подне. У ОШ „Десанка Максимовић“ у Косовској Каменици ученици српске и албанске националности имају заједничко двориште. У већ поменутој ОШ „Браћа Алексић“у у Липљану, у којој се за српске ученике настава одвија од уторка до суботе, албански ученици имају посебан улаз у школу. У месту Црквена Водица код Приштине, основну школу похађа 24 српска ученика и 55 албанских. Пре подне ученици из српске заједнице иду у ОШ „Доситеј Обрадовић“, а после подне ученици албанске националности иду у ОШ „Фазли Грајчевци“. Ови ученици деле исте учионице, али међусобно немају никакав контакт. У селу Понеш код Гњилана, такође под истим кровом, уче деца српске и албанске националности. Први иду у ОШ „Свети Сава“, а други у ОШ „Весељ Муља“. У овој школи је свега 29 српских ђака од првог до осмог разреда и троје које је у предшколском. Директори школе трвде да се настава одвија без проблема иако је школа мултиетничка и иако постоје паралелне структуре и два засебна образовна система.

28 У Липљану је понедељком пијачни дан па се процењује да је мање безбедно за српску децу да тада похађају наставу. 
Културни живот српских заједница на КиМ одвија се у складу са могућностима које дозвољава политичка ситуација. Манастири представљају центар српске културне баштине у овој области, па се често организују удружене посете. Домови културе који опстају у северном делу КиМ су места где се окупљају књижевници и уметници, али и гостујући глумци, организују позоришне представе, концерти и премијере филмова. Осим тога, током године се организују различите манифестације од којих су најпосећенији Видовдански дани. У сарадњи са локалном самоуправом и Канцеларијом за КиМ, ученици са КиМ сваке године организовано посећују Сајам књига у Београду.

\section{Закључак}

Након једностраног проглашења независности Косова* на целој територији КиМ постоје два језика у службеној употреби - српски и албански. У свим правним документима самопроглашеног Косова* ова два језика се третирају равноправно, мада је ситуација у пракси сасвим другачија. Бугарски (2005:82) то и објашњава као теоријску и функционалну равноправност у језику, где је прва неопходно полазиште сваке демократске језичке политике, а да се друга готово никад не може до краја постићи, што не значи да њој не треба тежити свим расположивим средствима. Осетљива и напета политичка ситуација, као и вишеструко бројнија албанска заједница утичу на експанзију албанског језика као већинског, па тако језици мањинских заједница, укључујући и српски, остају претежно у приватној употреби, ограничени на породично и мањинско окружење, често и из безбедносних разлога. Поред тога, мањинско-већински односи нису само ствар физичке величине, него и одраз друштвеног и политичког статуса и утицаја у средини.

Угрожавање статуса и нестајање српског језика са КиМ директно је повезано са смањењем броја српског становништва који њиме говори, као и са незнатним бројем припадника несрпских заједница који углавном недовољно познају српски језик или га на погрешан начин користе. У прилог томе говори и проблем квалитета превода различитих типова докумената као и топографских знакова услед недостатка професионалног особља или обучених преводилаца. Проблем смањења српског становништва треба решавати на највишем, државном нивоу уз планску и финансијску подршку, обезбеђивањем свих неопходних услова за живот. 
За успешно спровођење лингвистичких права на КиМ потребно је удружено и системско деловање угледних српских, локалних и европских институција уз стални надзор и контролу. У том смислу треба разматрати и сарадњу две до сада поменуте канцеларије - Канцеларије за Косово и Метохију из Београда и Канцеларије повереника за језике из Приштине. Ове две установе до сада нису оствариле никакав званичан контакт нити било који вид сарадње, чак ни у оквиру актуелних преговора у Бриселу у циљу нормализације односа. Канцеларија за КиМ има интерес да сарађује са Канцеларијом повереника за језике будући да у оквире њеног деловања спадају и култура и језик којим се културни садржаји преносе. Осим тога, овај проблем се тиче свих Срба, односно, становника КиМ којима је српски језик матерњи.

Такође, потребно је целокупно подизање свести о значају поштовања лингвистичких права на свим нивоима, подједнако унутар српске и албанске заједнице на КиМ. У мултиетничким и мултилингвалним срединама неопходно је изграђивање међусобног разумевања, поштовања, толеранције, осећаја равноправности, а све то је могуће кроз учење и наставу страних језика. Развијање комуникативне компетенције на два службена језика на КиМ је у интересу обе језичке заједнице јер она даје потенцијал нормализацији односа и побољшању услова живота у вишејезичној заједници за све. Осим тога, погодује очувању језичке разноликости, чији се значај упоређује са биодиверзитетом. Тове Скутнаб-Кангас (2002:14) тврди да је важно промовисати вишејезичност чак и када један доминантан језик, у овом случају албански, доноси много предности. Она објашњава да је еволуција потпомогнута разноликошћу, као и да су најјачи и најстабилнији екосистеми они који су најразноврснији. Језичка и културна разноликост повећавају шансе за успех и адаптацију. Земље које су језички и културно разнолике имају приступ различитим знањима и идејама. Зато и образовни систем у коме се инсистира на плурилингвизму производи не само културни и лингвистички капитал, већ и капитал знања који се може размењивати са другим типовима капитала на тржишту. Капитал знања и информација је оно што треба да удружи појединце у мултилингвалној средини на КиМ јер је интерес вишеструк. У скорије време, под покровитељством ОЕБС-а, запослени у јавним установама су почели да уче албански тј. српски како би могли да изађу у сусрет свим грађанима чији је језик службени и 
како би успешно применили све језичке одредбе из закона. У будућности је потребно интензивирати овакве иницијативе и уз финансијску подршку међународних организација промовисати двојезичност и вишејезичност као предност читаве друштвене заједнице не само на општинском нивоу и међу запосленима у државној администрацији већ и у почетној фази формалног образовног процеса. На тај начин би се постепено превазилазиле предрасуде код младих, од почетка развијао мултикултурални став, отворено размењивале информације и формирали едуковани европски грађани са израженом толеранцијом, вољом да сарађују са припадницима различитих култура и потребом за друштвеном хармонијом.

\section{ЛИТЕРАТУРА}

1. USAID (2017) Toward implementation of the Law on languages. Дocтупно преко: https://www.usaid.gov/kosovo/program-updates/feb-2017-towardimplementation-law-languages [1.9.2017]

2. USAID (2017) USAID Advancing Kosovo Together. Доступно преко: http://pdf.usaid.gov/pdf_docs/PA00MVRB.pdf [18.9.2017]

3. Bugarski, R. (2005). Jezik i kultura. Biblioteka XX vek

4. Bugarski, R. (2009). Nova lica jezika. Biblioteka XX vek

5. Doli, D., Cabiri, K., \& Korenica, F. (2010). Equalizing the Use of Language: A View to Kosovo Law's Guarantees Upon Minority Languages. Open Law Journal, 3, 6-14.

6. Duncan, D. (2016). Language policy, ethnic conflict, and conflict resolution: Albanian in the former Yugoslavia. Language Policy, 15(4), 453-474.

7. Office of the language commissioner (2015) Monitoring and Evaluation of Language Rights in Kosovo. Доступно преко: http://www.komisioneri-ks.org/ repository/docs/Anglisht_Finale_160315.pdf [17.11.2017]

8. MONT (2003). Nastavni plan i program za šesti razred niže srednje škole. Доступно преко: http://www.masht-gov.net/advCms/documents/ Uvodni\%20deo6.pdf [11.11.2017]

9. MONT (2008). Zakon o obrazovanju u opštinama Republike Kosovo. Доступно преко: http://www.masht-gov.net/advCms/documents/09_2008_03_ L068_sr.pdf [11.11.2017] 
10. MONT (2010). Nezavisna komisija za pregled nastavnog materijala na srpskom jeziku. Доступно преко: http://www.masht-gov.net/advCms/ documents/Sveobuhvatni_Izvestaj_Nezavisna_Komisija_za_pregled $\% 20$ nastavnog_materijala_na_srpskom_jeziku.pdf [11.111.2017]

11. MONT (2011a). Kosovo Education Strategic Plan 2011-2016. Доступно преко: http://www.masht-gov.net/advCms/documents/KESP_2011_2016. pdf [11.11.2017]

12. MONT (2011б). Zakon o preduniverzitetskom obrazovanju u Republici Kosovo*. Доступно преко: http://www.mashtgov.net/advCms/documents/04_ Ligji_per_arsimin_Parauniversitar_serbisht.pdf [11.11.2017]

13. МОНТ (2012) Курикулум Косова; основни курикулум за йреgиколски разреg и основно образовање на Косову. Доступно преко: http:/ eu.eduswap-ks.org/Guidebooks_and_KCC/KCC_Pre-Primary_and_PrimarySerbian.pdf, [19.9.2017]

14. Najvirtova, A., \& Burema, L. (2011). Assessing Minority Language Rights in Kosovo.

15. ОЕБС 2006: OSCE (2006). Minority Language Use in Municipalities of Kosovo Доступно преко: http://www.osce.org/kosovo/23187?download=true [20.11.2017]

16. ОЕБС 2008a: OSCE (2008a) Report on the linguistic rights of persons belonging to national minorities in the OSCE area. Доступно преко: http:// www.osce.org/hcnm/42060?download=true [20.11.2017]

17. ОЕБС 20086: ОSCE (20086) Implementation of the Law on the Use of Languages by Kosovo Municipalities- Доступно преко: http://www.osce.org/ kosovo/32762?download=true [20.11.2017]

18. ОЕБС 2009: OSCE (2009) Kosovo non-majority communities within the primary and secondary educational system. Доступно преко: http://www. osce.org/kosovo/36978?download=true [20.11.2017]

19. OSCE (2011) Višejezičko zakonodavstvo na Kosovu i njegovi izazovi Доступно преко: http://www.osce.org/sr/kosovo/87706?download=true [20.11.2017]

20. OSCE (2012) Izveštaj o proceni prava zajednica. Доступно преко: http://www.osce.org/sr/kosovo/92247?download=true, [21.11.2017]

21. OSCE (2014a) Freedom of media and safety of journalists in Kosovo Доступно преко: https://www.osce.org/kosovo/122390?download=true [20.11.2017]

22. OSCE (2014b) Municipal language compliance in Kosovo. Доступно преко: http://www.osce.org/kosovo/120010?download=true [20.11.2017] 
23. Council of Europe (1995), Framework Convention for the Protection of National Minorities, 1 February 1995, ETS 157. Доступно преко: https:// rm.coe.int/16800c10cf [16.10.2017]

24. Council of Europe (2013), Advisory Committee on the Framework convention for the protection of national minorities, Third Opinion on Kosovo* Доступно преко: https://rm.coe.int/168008c6c6 [27.9.2017]

25. Skutnabb-Kangas, T. (2002). Why should linguistic diversity be maintained and supported in Europe?: some arguments. Strasbourg: Council of Europe.

26. Skutnabb-Kangas, T. (2004). The right to mother tongue medium education-the hot potato in human rights instruments. In Opening plenary at the 2nd Mercator International Symposium, Tarragona, Spain (pp. 27-28).

27. Skutnabb-Kangas, T. (2006). Language policy and linguistic human rights, y: Ricento, Thomas (yp.) An introduction to language policy. Theory and method, Malden, MA, Blackwell Publishing,

28. Službeni list Republike Kosovo (2006) Zakon o upotrebi jezika br. 02/L-37

29. Službeni list Republike Kosovo (2008) Zakon o obrazovanju u opštinama br. 03/L-068

30. Službeni list Republike Kosovo (2008) Zakon o promovisanju prava zajednica i njihovih pripadnika u Republici Kosovo br. 03/L-047

31. Službeni list Republike Kosovo (2008) Ustav Republike Kosovo. Доступно преко: http://www.kryeministri-ks.net/repository/docs/Ustav1.pdf [17.9.2017]

32. UNICEF (2004) Obrazovanje dece manjina na Коsovu Доступно преко: http://www.unicef.org/kosovoprogramme/serb-ver-min.pdf [17.9.2017]

33. Phillopson, Robert, Language policy and linguistic imperialism. In: RICENTO, Thomas (ed.) (2006): An introduction to language policy. Theory and method, Malden, MA, Blackwell Publishing, p. 346-361.

34. Jansen, S. L. (2012). Serbian/Albanian Bilingualism in Kosova: Reversal or Entrenchment of the Curse of Babel? Доступно преко: http:// digitalcollections. sit.edu/cgi/viewcontent.cgi? article $=2303 \&$ context $=i s p$ collection [11.8.2017] 


\title{
Marija M. Lončar
}

\section{THE STATUS OF SERBIAN IN KOSOVO AND METOHIJA}

\begin{abstract}
Summary
The political and historical circumstances that led to a drastic reduction in the number of Serbs living on the territory of Kosovo and Metohija have had a tremendous impact on the real status of the Serbian language and culture in this region. Even though Albanian and Serbian are treated equally in official documents referring to the territory of Kosovo and Metohija, Albanian is practically used far more widely due to the fact that the Serbian language has been reduced to enclaves, especially in the southern part of the region. This paper is aimed at highlighting the longstanding and current problem of maintaining the Serbian language and cultural heritage on the territory of the self-proclaimed state of Kosovo by reviewing previous research and results obtained in the field of education and legislation. The paper examines the application of the linguistic rights guaranteed by the Constitution of the Republic of Kosovo* and makes proposals for the maintenance of the Serbian language in Kosovo and Metohija.
\end{abstract}

Key words: language policy, language/linguistic rights, bilingualism, ethnicity, native speaker, linguicide, linguistic imperialism 